\title{
Hyper Sudoku Solver dengan Menggunakan Harris Hawks Optimization Algorithm
}

\author{
Eric Dinata, Teknologi Informasi Institut Sains dan Teknologi Terpadu Surabaya, Herman Budianto, \\ Teknik Informatika Institut Sains dan Teknologi Terpadu Surabaya, dan Hendrawan Armanto, Teknik \\ Informatika Institut Sains dan Teknologi Terpadu Surabaya
}

\begin{abstract}
Abstrak-Sudoku merupakan salah satu permainan klasik yang digemari banyak orang. Sebagai salah satu permainan papan, Sudoku mempunyai banyak varian, salah satunya Hyper Sudoku. Hyper Sudoku mempunyai tingkat kesulitan yang lebih tinggi daripada Sudoku biasa. Tingkat kompleksitas yang tinggi membuat pemainan ini menjadi brain teaser yang baik dan sangat cocok diambil sebagai media untuk menguji algoritma metaheuristik. Algoritma yang populer pada dekade terakhir ini adalah algoritma metaheuristik berbasis populasi, yang mengadaptasi perilaku binatang dalam memecahkan permasalahan optimasi, salah satunya adalah Harris Hawks Optimization (HHO). Seperti kebanyakan metode swarm intelligence (SI) lainnya, algoritma ini mengandalkan proses diversification dan intensification. Selain itu, HHO mempunyai empat strategi khusus untuk mencari solusi dengan kondisi yang berbeda. HHO mampu mencakup solusi multi dimensi, sehingga sangat cocok diimplementasikan pada persoalan Hyper Sudoku. Pada proses pengujian, digunakan dua setting parameter yang berbeda, tiga macam persoalan Hyper Sudoku, dan tiga puluh independent run untuk mencapai hasil yang diinginkan. Berdasarkan hasil pengujian, dapat disimpulkan bahwa tingkat keberhasilan untuk mencari solusi pada persoalan Hyper Sudoku dengan menggunakan HHO berkisar antara 86 hingga $88 \%$, dilihat dari fitness value-nya.
\end{abstract}

Kata Kunci-HHO, Hyper Sudoku, metaheuristik, optimasi.

\section{Pendahuluan}

$\mathrm{P}$ ermasalahan optimasi yang ada pada kehidupan seharihari, sering kali tidak dapat diselesaikan dengan persamaan matematika biasa. Hal ini membuat banyak orang mencoba melakukan pendekatan dengan algoritma metaheuristik. Algoritma metaheuristik secara umum dapat dibagi menjadi tiga kategori, yaitu physical-based, evolutionary-based, dan swarm-based. Beberapa metode yang populer meliputi Genetic Algorithms (GA), Particle Swarm Optimization (PSO), dan Ant Colony Optimization (ACO).

Dalam dekade terakhir, muncul banyak metode swarmbased dengan menggunakan nama-nama hewan, karena

Eric Dinata, Teknologi Informasi Institut Sains dan Teknologi Terpadu Surabaya, Surabaya, Jawa Timur, Indonesia (e-mail: eric.dinata@gmail.com)

Herman Budianto, Teknik Informatika Institut Sains dan Teknologi Terpadu Surabaya, Surabaya, Jawa Timur, Indonesia (e-mail: herman.budianto@gmail.com)

Hendrawan Armanto, Teknik Informatika Institut Sains dan Teknolog Terpadu Surabaya, Surabaya, Jawa Timur, Indonesia (e-mail: hendrawan@stts.edu) memang metode ini mengimplementasikan perilaku natural dari jenis-jenis hewan tertentu pada algoritmanya, yang dianggap efektif dalam mencari solusi dalam masalah optimasi. Penelitian ini membahas sebuah metode baru yang dipublikasikan pada tahun 2019, yaitu Harris Hawks Optimization. Algoritma ini menggunakan pendekatan dari sekumpulan elang yang memantau dan mengepung mangsanya. Algoritma ini juga menggunakan dua fase, yakni exploration (diversification) dan exploitation (intensification). Kedua fase ini umum dipakai pada metodemetode yang menggunakan Swarm Intelligence (SI).

Untuk permasalahan optimasi yang dipakai, penelitian ini menggunakan permainan Hyper Sudoku sebagai pokok masalah. Di mana permainan ini merupakan varian dari permainan Sudoku yang populer sejak tahun 1979, baik secara kertas maupun online. Hyper Sudoku juga sering dikenal sebagai Windoku, Four-square Sudoku, dan NRC Sudoku (pertama kali muncul pada koran Belanda NRC Handelsblad). Seperti yang kita ketahui, Sudoku standar memakai grid 9x9 dan memiliki aturan pokok, yaitu tidak boleh ada angka yang sama pada setiap baris, setiap kolom, dan setiap area yang ditentukan, dalam hal ini, sembilan area 3x3. Sedangkan Hyper Sudoku memiliki aturan tambahan, yaitu adanya area tambahan sebanyak empat kotak 3x3 (Four-square Sudoku) yang menyerupai jendela (Windoku).

\section{HARRIS HAWKS OPTIMIZATION}

Harris Hawks Optimization [1]merupakan populationbased metaheuristic algorithm, dengan memimik pergerakan natural dari sekumpulan burung elang jenis Harris dalam mencari mangsa.

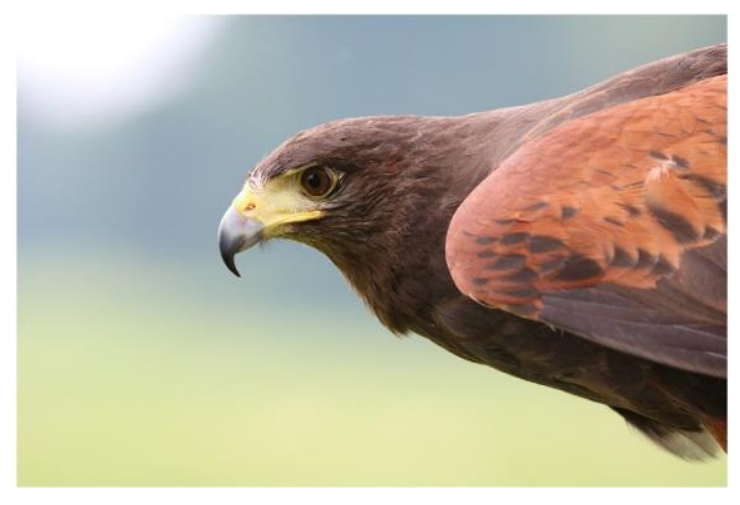

Gambar. 1. Elang Harris

Kunci utama dari HHO adalah perilaku kooperatif dan gaya pengejaran para elang yang disebut sebagai surprise 
pounce (terkaman kejutan). Strategi ini dilakukan bersamasama dengan cara mengepung sang mangsa dari berbagai arah. Ada beberapa pola pengejaran yang bisa dilakukan, bergantung pada berbagai skenario dan pola sang mangsa untuk melarikan diri. Dari berbagai pola tersebut, maka dibentuklah algoritma optimasinya.

Seperti kebanyakan metode swarm intelligence (SI) lainnya, HHO dibagi menjadi dua fase, yaitu fase exploration (eksplorasi) dan fase exploitation (exploitasi). Yang unik di $\mathrm{HHO}$ adalah adanya perching strategies (strategi hinggap para elang) pada fase exploration dan escaping behavior (perilaku melarikan diri mangsa) pada fase exploitation.

Ada beberapa pengembangan algoritma HHO, seperti Harris Hawks optimization with information exchange [2](IEHHO), yang menambahkan adanya pertukaran informasi antar elang, dan Horizontal and vertical crossover of Harris hawk optimizer with Nelder-Mead simplex for parameter estimation of photovoltaic models [3] (CCNMHHO), yang menambahkan crisscross optimizer dan Nelder-Mead simplex algorithm, yang dipakai dalam perhitungan solar power system (sistem tenaga surya).

\section{A. Fase pada $\mathrm{HHO}$}

Variabel $E$ adalah energi sang mangsa untuk melarikan diri. Jika nilai $|E| \geq 1$, berarti energi sang mangsa masih sangat banyak, bisa berpindah tempat dengan cepat, sehingga pada saat ini para elang memasuki fase pencarian, atau fase exploration. Sedangkan jika nilai $|E|<1$, maka dimulailah fase exploitation, dengan catatan apabila $|E| \geq$ 0.5 , maka akan memasuki fase soft besiege dan apabila $|E|<0.5$, maka akan memasuki fase hard besiege.

Variabel q adalah strategi hinggap, jika nilai $q<0.5$, maka elang akan hinggap pada suatu posisi, dengan memperhitungkan posisi elang-elang lainnya. Jika nilai $q \geq$ 0.5 , maka elang akan hinggap pada pohon random atau bisa dibilang posisi random.

Variabel $r$ adalah kemungkinan sang mangsa untuk melarikan diri. Jika nilai $r<0.5$, maka kemungkinan sang mangsa untuk melarikan diri adalah besar. Sebaliknya, jika nilai $r \geq 0.5$, maka kemungkinan mangsa untuk melarikan diri adalah kecil.

\section{B. Fase exploration}

Pada fase ini, para elang akan melacak dan mendeteksi sang mangsa dengan penglihatan tajam mereka. Namun, hal ini tidak selalu mudah, dikarenakan sang mangsa sering kali tidak begitu saja muncul di area penglihatan para elang. Oleh karena itu, para elang akan menunggu, mengamati, dan memantau untuk mencari mangsa, bahkan sampai berjamjam.

Pada HHO, para elang ibarat kandidat solusi dan kandidat terbaik pada setiap iterasi adalah yang mempunyai posisi yang sama dengan sang mangsa, atau yang paling mendekati.

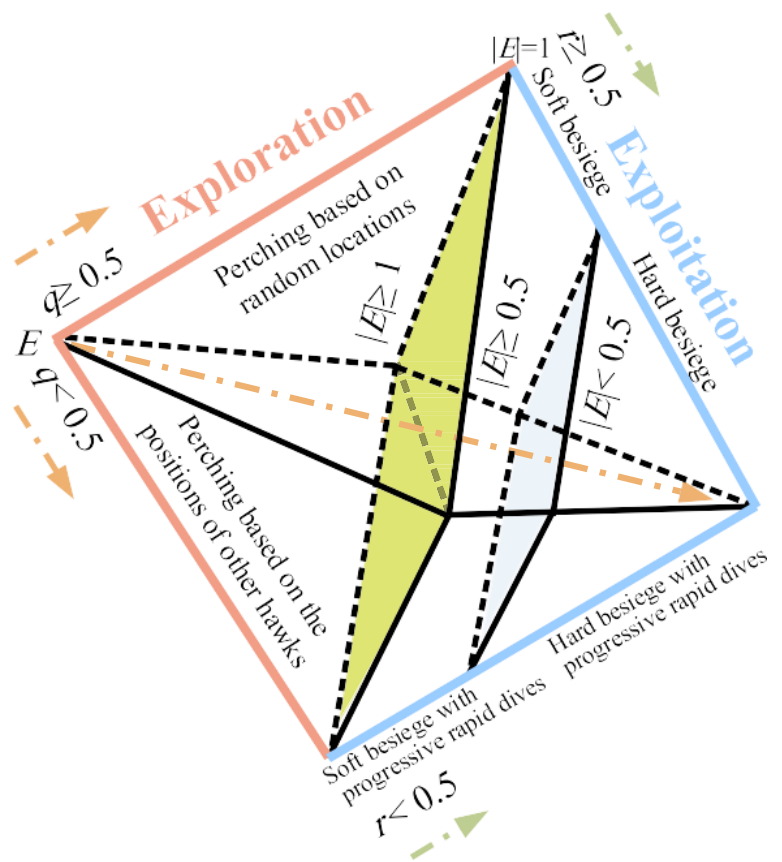

Gambar. 2. Fase pada algoritma Harris Hawks Optimization

\section{Psedocode dari HHO}

Input: jumlah populasi $(N)$ dan maksimum iterasi $(T)$

Output: posisi kelinci dan fitness valuenya

Inisialisasi populasi random $X_{i}(i=1,2, \ldots, N)$

while (kondisi berhenti belum tercapai) do

Hitung fitness value elang

Set $X_{\text {rabbit }}$ sebagai posisi kelinci (best location)

for (setiap elang $\left(X_{i}\right)$ ) do

Update energi awal $\left(E_{0}\right)$ dan kekuatan lompat $(J)$

$\mathrm{E}_{0}=2 \mathrm{rand}()-1$

$\mathrm{J}=2(1-\mathrm{rand}())$

Update energi dengan persamaan (3)

Fase eksplorasi

if $(|E| \geq 1)$ then

Update lokasi dengan persamaan (1)

Fase eksploitasi

if $(|E|<1)$ then

Soft besiege

if $(r \geq 0.5$ and $|E| \geq 0.5)$ then

Update lokasi dengan persamaan (4)

Hard besiege

else if $(r \geq 0.5$ and $|E|<0.5)$ then

Update lokasi dengan persamaan (6)

Soft besiege with progressive rapid dives

else if $(r<0.5$ and $|E| \geq 0.5)$ then

Update lokasi dengan persamaan (10)

Hard besiege with progressive rapid dives

else if $(r<0.5$ and $|E|<0.5)$ then

Update lokasi dengan persamaan (11)

$\underline{\text { Return } X_{\text {rabbit }}}$

Pada fase ini terdapat dua strategi, yang pertama, seekor elang akan hinggap pada suatu posisi dimana posisi ini dihitung atau ditentukan dari posisi kawan-kawannya dan juga posisi mangsa (supaya mereka berada pada posisi yang cukup dekat untuk menerkam mangsa), ini digambarkan pada persamaan 1 , di mana kondisi $q<0.5$, dan yang kedua, seekor elang akan hinggap pada posisi random, di mana 
pada dunia nyata posisi ini adalah letak pepohonan yang dihinggapi oleh para elang tersebut, ini digambarkan pada persamaan 1 , dengan kondisi $q \geq 0.5$.

$$
\begin{aligned}
& X(t+1)= \\
& \left\{\begin{array}{cc}
X_{\text {rand }}(t)-r_{1}\left|X_{\text {rand }}(t)-2 r_{2} X(t)\right| & (1) \\
\left(X_{\text {rabbit }}(t)-X_{m}(t)\right)-r_{3}\left(L B+r_{4}(U B-L B)\right) & q<0.5
\end{array}\right.
\end{aligned}
$$

Variabel $q$ merupakan perching strategies (strategi hinggap), di mana $X(t+1)$ adalah posisi vector dari para elang pada iterasi selanjutnya, $X_{\text {rabbit }}(t)$ adalah posisi dari sang mangsa, kelinci, kemudian $X(t)$ adalah posisi vector para elang yang sekarang. Variabel $r_{1}, r_{2}, r_{3}, r_{4}$, dan $q$ adalah angka random di antara 0 dan 1 , yang akan berganti terus pada setiap iterasi, kemudian $L B$ dan $U B$ adalah batas bawah (lower bound) dan atas (upper bound) untuk setiap variabel. $X_{\text {rand }}(t)$ adalah elang yang dipilih secara acak dari populasi saat ini, dan $X_{m}$ adalah rata-rata posisi elang dari populasi saat ini.

Untuk menghitung rata-rata posisi elang dari populasi saat ini, digunakan persamaan berikut:

$$
X_{m}(t)=\frac{1}{N} \sum_{i=1}^{N} X_{i}(t)
$$

Di mana $X_{i}(t)$ merupakan lokasi dari setiap elang pada iterasi $t$ dan $N$ merupakan jumlah total elang.

\section{Transisi dari exploration ke exploitation}

Algoritma HHO akan mengalami transisi dari fase exploration ke fase exploitation. Kemudian, akan terjadi perubahan exploitative behavior (perilaku eksploitasi), yang bergantung pada escaping energy (tenaga untuk melarikan diri) dari sang mangsa dan juga chance of prey escaping (kemungkinan sang mangsa untuk berhasil melarikan diri). Untuk memodelkan kondisi ini, maka digunakan persamaan sebagai berikut:

$E=2 E_{0}\left(1-\frac{t}{T}\right)$

Di mana $E$ merupakan tenaga untuk melarikan diri sang mangsa, $T$ adalah jumlah maksimum iterasi, dan $E_{0}$ adalah energi awal sang mangsa. Pada $\mathrm{HHO}, E_{0}$ akan berganti secara acak pada setiap iterasi, dengan interval antara -1 dan 1. Jika nilai dari $E_{0}$ menurun dari 0 ke -1, maka itu berarti si kelinci melemah secara fisik. Sedangkan, sebaliknya, jika nilai $E_{0}$ naik dari 0 ke 1 , maka itu berarti si kelinci mengalami penguatan secara fisik. Dinamika energi untuk melarikan diri ini cenderung mengalami penurunan pada proses iterasi. Pada saat $|E| \geq 1$, para elang akan mencari pada area yang berbeda untuk menjelajahi lokasi sang mangsa, yaitu dengan dilakukannya fase exploration. Sedangkan pada saat $|E|<1$, algoritma ini akan memanfaatkan solusi-solusi yang berdekatan (neighborhood) pada fase exploitation. Singkatnya, fase exploration terjadi saat $|E| \geq 1$, sedangkan fase exploitation akan terjadi setelahnya, pada saat $|E|<1$.

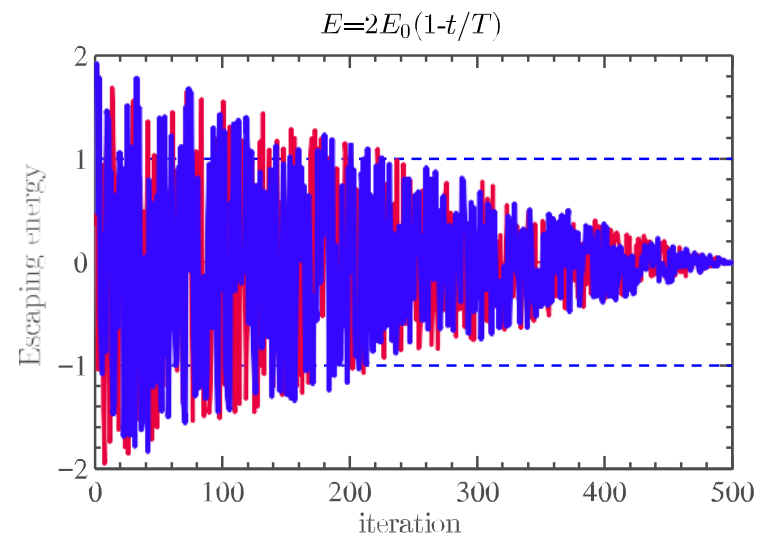

Gambar. 3. Hasil simulasi $E$

Simulasi $E$ ini dilakukan dua kali, dengan jumlah iterasi masing-masing 500. Terdapat garis berwarna biru dan merah, yang mewakili simulasi pertama dan ke-dua. Seperti yang terlihat di gambar 3, escaping energy atau tenaga yang dimiliki sang mangsa untuk melarikan diri semakin lama akan semakin berkurang, atau mendekati 0 .

\section{Fase exploitation}

Pada fase ini, para elang Harris akan melakukan surprise pounce (terkaman kejutan), atau disebut juga sebagai seven kills, dengan cara menyerang mangsa yang telah dideteksi pada fase sebelumnya. Akan tetapi, secara natural, sang mangsa akan sering kali mencoba untuk melarikan diri. Oleh karena itu, diperlukan strategi pengejaran yang berbeda pada kondisi sebenarnya. Berdasarkan dari perilaku melarikan diri dari sang mangsa dan strategi pengejaran para elang, maka ada empat macam strategi yang bisa dilakukan, yaitu soft besiege, hard besiege, soft besiege with progressive rapid dives, dan hard besiege with progressive rapid dives.

Sang mangsa akan selalu mencoba untuk melarikan diri dari situasi yang mengancam dirinya. Variabel $r$ adalah besarnya peluang dari sang mangsa untuk berhasil melarikan diri (jika $r<0.5$ ) dan gagal untuk melarikan diri (jika $r \geq$ $0.5)$, sebelum surprise pounce. Apapun yang dilakukan sang mangsa, para elang akan melakukan hard besiege atau soft besiege untuk menangkap mangsa tersebut. Itu berarti para elang akan mengitari sang mangsa dari arah yang berbeda, secara hard atau soft, tergantung dari energi yang tersisa dari sang mangsa. Pada situasi sebenarnya, para elang akan mendekat perlahan-lahan menuju sang mangsa untuk memperbesar kesempatan mereka dalam bekerja sama membunuh sang mangsa dengan melakukan surprise pounce. Setelah beberapa menit, sang mangsa akan kehilangan banyak tenaga. Kemudian, para elang akan memperkuat proses pengepungan untuk menangkap sang mangsa yang sudah kehilangan banyak tenaga tersebut. Untuk memodelkan strategi ini dan menentukan apakah HHO akan menggunakan strategi soft besiege atau hard besiege, maka parameter $E$ akan digunakan.

Dalam hal ini, jika $|E| \geq 0.5$, maka strategi soft besiege akan digunakan, dan jika $|E|<0.5$, maka strategi hard besiege yang akan digunakan. 


\section{E. Soft besiege}

Pada saat sang mangsa masih mempunyai tenaga yang cukup untuk melarikan diri dan kemudian mencoba untuk melompat ke sana kemari, para elang akan mengelilinginya secara perlahan, dengan tujuan untuk membuat sang mangsa kehabisan tenaga dan pada akhirnya akan melakukan surprise pounce (terkaman kejutan). Strategi ini terjadi jika $r \geq 0.5$ dan $|E| \geq 0.5$. Perilaku ini digambarkan dengan persamaan berikut:

$X(t+1)=\Delta X(t)-E\left|J X_{\text {rabbit }}(t)-X(t)\right|$

$\Delta X(t)=X_{\text {rabbit }}(t)-X(t)$

Di mana $\Delta X(t)$ adalah selisih antara posisi vector sang mangsa dan lokasi saat ini, pada iterasi $t$. Variabel $r_{5}$ merupakan angka random di antara 0 dan 1 , yang akan digunakan untuk menghitung $J=2\left(1-r_{5}\right)$, yang merupakan kekuatan melompat kelinci sepanjang proses melarikan diri. Nilai $J$ akan berganti dengan nilai acak pada setiap iterasi, untuk men-simulasi pergerakan natural kelinci.

\section{F. Hard besiege}

Pada saat sang mangsa sudah kehabisan tenaga dan kemungkinan untuk melarikan diri semakin kecil, maka para elang tidak lagi mengelilinginya secara perlahan, namun sudah bersiap untuk melakukan surprise pounce. Strategi ini terjadi jika $r \geq 0.5$ dan $|E|<0.5$. Pada situasi ini, posisi elang pada iterasi selanjutnya akan dihitung dengan menggunakan persamaan berikut:

$X(t+1)=X_{\text {rabbit }}(t)-E|\Delta X(t)|$

Model sederhana untuk menggambarkan langkah ini, dapat dilihat dari gambar berikut, dengan menggunakan satu ekor elang sebagai contoh:

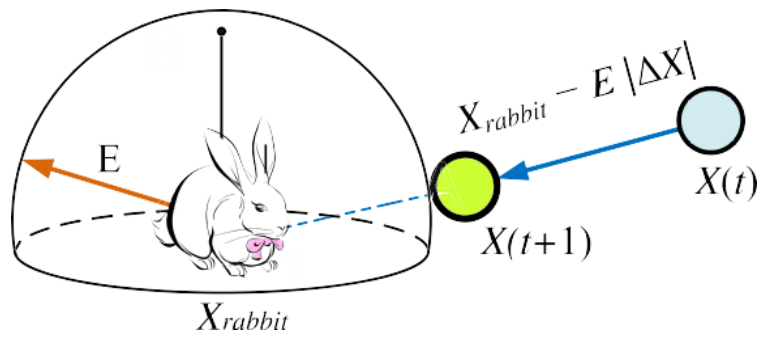

Gambar. 4. Contoh vector pada hard besiege

\section{G. Soft besiege with progressive rapid dives}

Pada saat sang mangsa masih mempunyai tenaga yang cukup untuk melarikan diri, para elang tetap akan melakukan soft besiege sebelum melakukan surprise pounce. Strategi ini terjadi jika $|E| \geq 0.5$, namun $r<0.5$.

Untuk memodelkan pola pergerakan melarikan diri dari sang mangsa dan juga leapfrog movement (pergerakan melompat), maka digunakanlah fungsi levy flight $(L F)$. Fungsi $L F$ ini digunakan untuk meniru pergerakan zigzag (berkelok-kelok) dari sang mangsa pada saat melarikan diri, serta pergerakan tidak teratur dari para elang pada saat melakukan rapid dives (pergerakan menukik secara cepat) untuk menangkap sang mangsa.

Untuk melakukan soft besiege, para elang akan mengevaluasi untuk menentukan pergerakan mereka selanjutnya melalui persamaan berikut:

$Y=X_{\text {rabbit }}(t)-E\left|J X_{\text {rabbit }}(t)-X(t)\right|$

Kemudian, mereka akan membandingkan pergerakan ini dengan pergerakan sebelumnya untuk menentukan apakah itu merupakan sebuah pergerakan yang bagus atau tidak. Jika tidak, maka mereka akan mulai melakukan pergerakan yang tidak teratur dan mendadak untuk mendekati sang mangsa. Pergerakan ini akan digambarkan melalui persamaan berikut:

$Z=Y+S \times L F(D)$

Di mana $D$ adalah dimensi dari masalah, $S$ adalah vector random dengan ukuran $1 \times D$, dan $L F$ adalah fungsi levy flight, yang dapat dihitung dengan menggunakan persamaan berikut:

$L F(x)=0.01 \times \frac{u \times \sigma}{|v|^{\frac{1}{\beta}}}, \sigma=\left(\frac{\Gamma(1+\beta) \times \sin \left(\frac{\pi \beta}{2}\right)}{\Gamma\left(\frac{1+\beta}{2}\right) \times \beta \times 2\left(\frac{\beta-1}{2}\right)}\right)^{\frac{1}{\beta}}$

Di mana $u$ dan $v$ merupakan bilangan random di antara 0 dan 1 , kemudian $\beta$ adalah konstanta yang ditetapkan pada nilai 1.5.

Pada akhirnya, untuk meng-update posisi para elang pada fase soft besiege ini, digunakanlah persamaan sebagai berikut:

$X(t+1)= \begin{cases}Y & \text { if } F(Y)<F(X(t)) \\ Z & \text { if } F(Z)<F(X(t))\end{cases}$

Di mana nilai $Y$ dan $Z$ didapatkan dari persamaan (7) dan (8). Ilustrasi sederhana langkah ini dapat dilihat pada gambar berikut, dengan menggunakan seekor elang sebagai contoh:

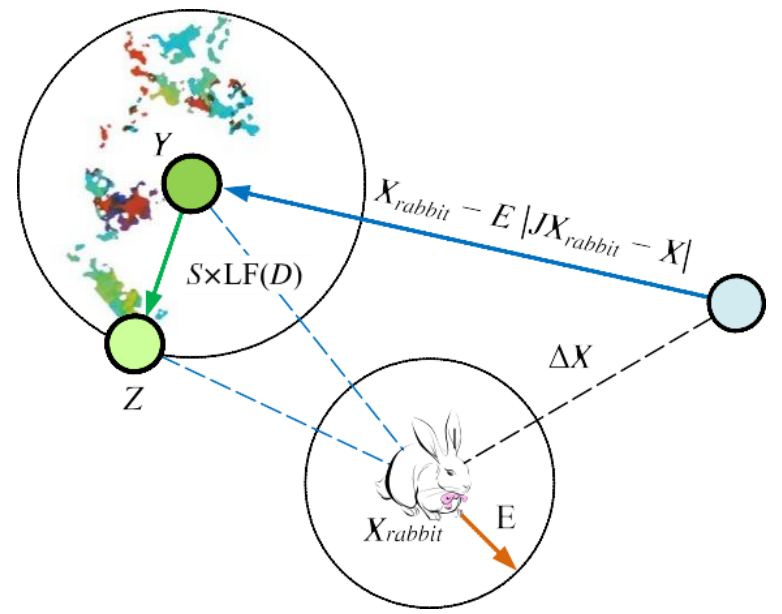

Gambar. 5. Contoh vector pada soft besiege with progressive rapid dives 
Pada gambar 5 ini, terdapat titik-titik berwarna-warni, yang merupakan jejak lokasi dari pola perhitungan $L F$ sebelumnya, yang kemudian mencapai posisi $Z$. Pada setiap langkah, hanya posisi $Y$ atau $Z$ yang lebih baik saja yang akan dipilih sebagai posisi selanjutnya. Strategi ini akan diterapkan pada setiap elang yang ada pada populasi.

\section{H. Hard besiege with progressive rapid dives}

Pada saat sang mangsa sudah tidak mempunyai tenaga yang cukup untuk melarikan diri, maka para elang akan melakukan hard besiege sebelum melakukan surprise pounce. Situasi pada langkah ini mirip dengan pada langkah soft besiege, hanya saja, pada langkah ini para elang mencoba memperkecil jarak rata-rata mereka dengan sang mangsa. Strategi ini terjadi jika $|E|<0.5$ dan $r<0.5$. Oleh karena itu, digunakanlah persamaan berikut:

$X(t+1)= \begin{cases}Y & \text { if } F(Y)<F(X(t)) \\ Z & \text { if } F(Z)<F(X(t))\end{cases}$

Di mana nilai $Y$ dan $Z$ didapatkan dari persamaan berikut:

$Y=X_{\text {rabbit }}(t)-E\left|J X_{\text {rabbit }}(t)-X_{m}(t)\right|$

$Z=Y+S \times L F(D)$

Variabel $X_{m}(t)$ dapat dihitung dengan menggunakan persamaan (2.2). Ilustrasi sederhana dari langkah ini dapat dilihat dari dua gambar berikut:

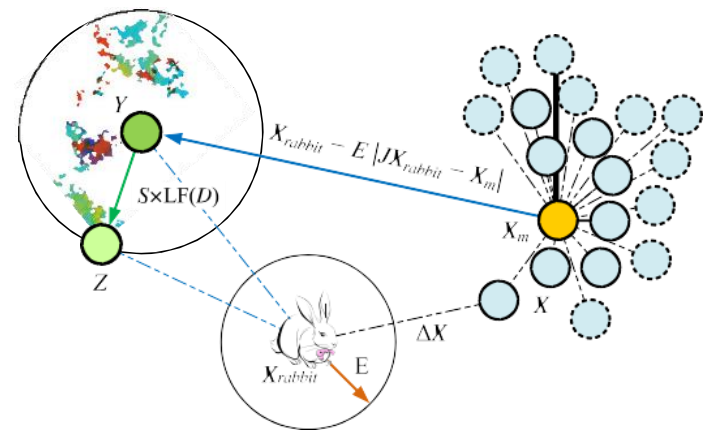

Gambar. 6. Contoh vector pada hard besiege with progressive rapid dives (2D)

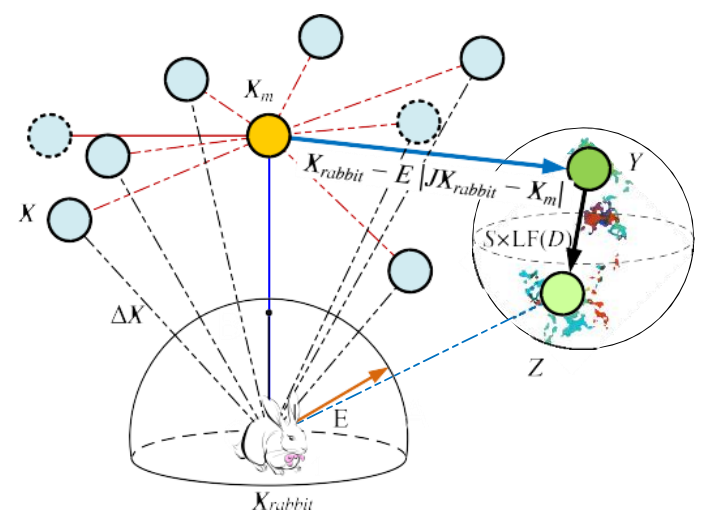

Gambar. 6. Contoh vector pada hard besiege with progressive rapid dives (3D)
Seperti halnya pada soft besiege with progressive rapid dives, titik-titik berwarna-warni merupakan jejak lokasi dari pola perhitungan $L F$ sebelumnya dan hanya nilai $Y$ atau $Z$ saja yang akan dipakai sebagai posisi baru pada iterasi selanjutnya.

\section{HYPER SUDOKU}

Hyper Sudoku[4], [5] merupakan varian dari Sudoku standar, yang memiliki besar grid yang sama (9x9), yang terdiri dari 9 region 3x3. Yang membedakan Hyper Sudoku dari Sudoku standar adalah adanya 4 tambahan region ${ }^{[6][7]}$, yang mengarah kepada adanya constraint tambahan, tidak boleh ada angka kembar pada region tambahan ini.

Angka-angka awal yang diberi dinamakan sebagai givens[6], [7]. Jumlah givens tidak mempengaruhi tingkat kesulitan. Untuk mencapai Sudoku dengan solusi unik, jumlah givens minimal untuk Sudoku standar adalah 17, sedangkan untuk Hyper Sudoku belum diketahui pasti, namun telah ditemukan persoalan Hyper Sudoku dengan 11 givens. Sudoku dengan solusi unik dinamakan sebagai proper $^{[7]}$ Sudoku.

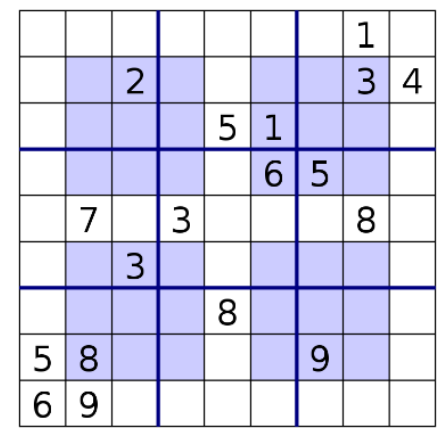

Gambar. 7. Hyper Sudoku

Constraint pada Sudoku [8]:

1) Angka harus berada pada range 1 sampai dengan 9

2) Tidak ada angka yang sama pada setiap baris

3) Tidak ada angka yang sama pada setiap kolom

4) Tidak ada angka yang sama pada setiap region Constraint pada Hyper Sudoku:

5) Tidak ada angka yang sama pada setiap region tambahan

Setiap constraint pada Hyper Sudoku ini akan dipakai untuk menghitung fitness value dalam satu solusi.

\section{IMPLEMENTASI}

Implementasi algoritma HHO diawali dengan inisialisasi populasi elang, dengan angka random dalam batasan 0 (batas bawah) sampai dengan 1 (batas atas). Seekor elang mewakili satu solusi, di mana satu solusi mempunyai 81 dimensi (81 angka) yang di-sort secara per baris dan diberi indeks. Sembilan angka pertama mewakili baris pertama, sembilan angka ke-dua mewakili baris ke-dua, dan seterusnya. Dengan diberi indeks dan pengurutan per baris, maka dijamin tidak ada angka yang sama pada setiap baris. 
TABEL I

INISIALISASI SOLUSI HYPER SUDOKU DENGAN HHO

\begin{tabular}{ccccc}
\hline \hline X & unsorted & u-index & sorted & s-index \\
\hline 1 & 0.0185268 & 1 & 0.0185268 & 1 \\
2 & 0.0751726 & 2 & 0.0751726 & 2 \\
3 & 0.1938518 & 5 & 0.1418404 & 3 \\
4 & 0.2032932 & 3 & 0.1938518 & 4 \\
5 & 0.1418404 & 4 & 0.2032932 & 5 \\
6 & 0.8858696 & 9 & 0.2326893 & 6 \\
7 & 0.44012 & 7 & 0.44012 & 7 \\
8 & 0.6946542 & 8 & 0.6946542 & 8 \\
9 & 0.2326893 & 6 & 0.8858696 & 9 \\
\hline \hline
\end{tabular}

Angka yang ditampilkan mewakili baris pertama saja (sembilan angka pertama).

Angka-angka awal (unsorted) akan diurutkan (sorted), kemudian diberi indeks ( $s$-index), setelah itu akan dilakukan reverse indexing untuk mengetahui indeks pada angkaangka awal (u-index).

Setelah itu, fitness value akan dihitung untuk setiap solusi, dengan cara menghitung banyaknya pelanggaran constraint terlebih dahulu:

1) Menghitung jumlah kotak kosong (a)

2) Menghitung jumlah kotak yang melanggar constraint baris (b)

3) Menghitung jumlah kotak yang melanggar constraint kolom (c)

4) Menghitung jumlah kotak yang melanggar constraint region awal pada Sudoku (d)

5) Menghitung jumlah kotak yang melanggar constraint region tambahan pada Hyper Sudoku (e)

Error $=\frac{1}{5}\left(\frac{(a+b+c+d)}{81}+\frac{e}{36}\right)$

Variabel a, b, c, dan d dibagi 81 karena angka maksimum pada constraint-constraint tersebut bernilai 81 (dari kotak 9x9). Sedangkan untuk variabel e dibagi 36 dikarenakan angka maksimum untuk constraint ini bernilai 36 (dari 4 kotak $3 \times 3$ ).

Berikutnya, karena Error adalah besarnya pelanggaran constraint dalam bentuk persentase (antara 0 dan 1), maka untuk menghitung fitness value $(F V)$, digunakan persamaan sebagai berikut:

$F V=1-$ Error

Nilai fitness value berkisar antara 0 dan 1 , di mana nilai 0 merupakan yang paling jelek dan nilai 1 merupakan yang paling baik. Jika fitness value bernilai 1, berarti solusi untuk soal Hyper Sudoku telah berhasil ditemukan.

Setelah proses inisialisasi, solusi dengan fitness value terbaik akan dipakai sebagai patokan awal, atau pada HHO dipakai istilah kelinci $\left(X_{\text {rabbit }}\right)$ dan pada setiap iterasi dan fase yang dilalui setiap elang, elang terbaik akan dibandingkan dengan solusi terbaik tersebut. Apabila elang baru mempunyai fitness value yang lebih baik, maka $X_{\text {rabbit }}$ akan di-update, apabila tidak, maka $X_{\text {rabbit }}$ yang lama-lah yang akan dipakai untuk iterasi berikutnya.

\section{UJI COBA}

Uji coba yang dilakukan adalah uji coba parameter, yaitu jumlah populasi, jumlah maksimum iterasi, dan juga jumlah independent run. Ada dua setting parameter yang diujicobakan, yang pertama adalah jumlah populasi 20 dengan jumlah maksimum iterasi 100. Kemudian yang ke-dua adalah jumlah populasi 30 dengan jumlah maksimum iterasi 500. Ke-dua setting parameter ini diuji-cobakan pada tiga soal Hyper Sudoku yang memiliki jumlah givens yang berbeda, masing-masing dilakukan 30 independent run.

TABEL II

UJI COBA HHO PADA HYPER SUDOKU DENGAN 30 RUN

\begin{tabular}{lcccccc}
\hline \hline HHO & $\mathrm{A} 1$ & $\mathrm{~A} 2$ & $\mathrm{~B} 1$ & $\mathrm{~B} 2$ & $\mathrm{C} 1$ & $\mathrm{C} 2$ \\
\hline Givens & 15 & 15 & 18 & 18 & 19 & 19 \\
Populasi & 20 & 30 & 20 & 30 & 20 & 30 \\
Iterasi & 100 & 500 & 100 & 500 & 100 & 500 \\
Run & 30 & 30 & 30 & 30 & 30 & 30 \\
Avg Time (s) & 3.95 & 22.14 & 4.09 & 27.56 & 4.03 & 27.88 \\
Avg Fitness & 0.868 & 0.883 & 0.868 & 0.88 & 0.873 & 0.883 \\
Run-1 & 0.87 & 0.884 & 0.86 & 0.894 & 0.854 & 0.88 \\
Run-2 & 0.852 & 0.87 & 0.871 & 0.886 & 0.888 & 0.931 \\
Run-3 & 0.873 & 0.881 & 0.867 & 0.888 & 0.867 & 0.851 \\
Run-4 & 0.882 & 0.878 & 0.872 & 0.87 & 0.895 & 0.873 \\
Run-5 & 0.87 & 0.88 & 0.87 & 0.875 & 0.882 & 0.896 \\
Run-6 & 0.869 & 0.878 & 0.87 & 0.865 & 0.875 & 0.874 \\
Run-7 & 0.877 & 0.867 & 0.865 & 0.886 & 0.875 & 0.867 \\
Run-8 & 0.87 & 0.869 & 0.874 & 0.875 & 0.871 & 0.875 \\
Run-9 & 0.888 & 0.879 & 0.87 & 0.87 & 0.86 & 0.882 \\
Run-10 & 0.869 & 0.857 & 0.872 & 0.876 & 0.873 & 0.873 \\
Run-11 & 0.86 & 0.901 & 0.872 & 0.87 & 0.881 & 0.881 \\
Run-12 & 0.884 & 0.885 & 0.873 & 0.869 & 0.862 & 0.886 \\
Run-13 & 0.849 & 0.861 & 0.86 & 0.867 & 0.869 & 0.875 \\
Run-14 & 0.852 & 0.88 & 0.862 & 0.873 & 0.873 & 0.873 \\
Run-15 & 0.873 & 0.906 & 0.872 & 0.888 & 0.869 & 0.89 \\
Run-16 & 0.844 & 0.896 & 0.875 & 0.885 & 0.873 & 0.891 \\
Run-17 & 0.854 & 0.889 & 0.858 & 0.88 & 0.857 & 0.876 \\
Run-18 & 0.898 & 0.898 & 0.874 & 0.862 & 0.876 & 0.877 \\
Run-19 & 0.863 & 0.889 & 0.864 & 0.886 & 0.893 & 0.88 \\
Run-20 & 0.864 & 0.886 & 0.856 & 0.886 & 0.872 & 0.894 \\
Run-21 & 0.859 & 0.881 & 0.864 & 0.877 & 0.864 & 0.901 \\
Run-22 & 0.874 & 0.877 & 0.873 & 0.901 & 0.876 & 0.893 \\
Run-23 & 0.876 & 0.906 & 0.874 & 0.886 & 0.86 & 0.868 \\
Run-24 & 0.864 & 0.901 & 0.857 & 0.885 & 0.886 & 0.874 \\
& & & & & & \\
\hline
\end{tabular}

Huruf A mewakili soal A, begitu juga dengan huruf B dan C.

Sedangkan angka pada A1 merupakan setting parameter 1 dan angka pada A2 merupakan setting parameter 2 .

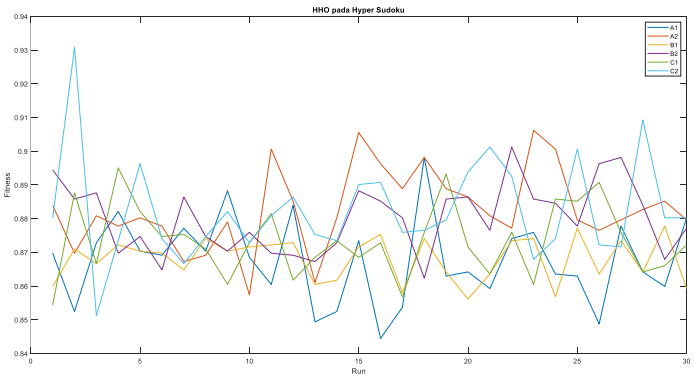

Gambar. 8. Grafik uji coba HHO pada Hyper Sudoku dengan 3 jenis persoalan, 2 macam setting parameter, dan 30 run.

Ada tiga jenis soal Hyper Sudoku dengan jumlah givens yang berbeda-beda yang digunakan pada uji coba ini, yakni soal A dengan jumlah givens sebanyak 15, soal B dengan 18, dan soal C dengan 19. 


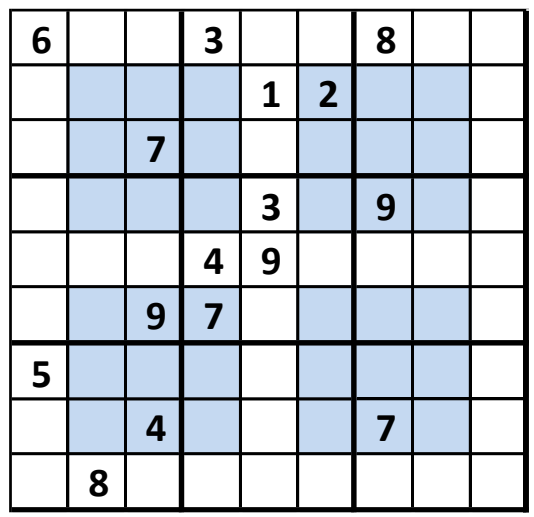

Gambar. 9. Soal Hyper Sudoku A

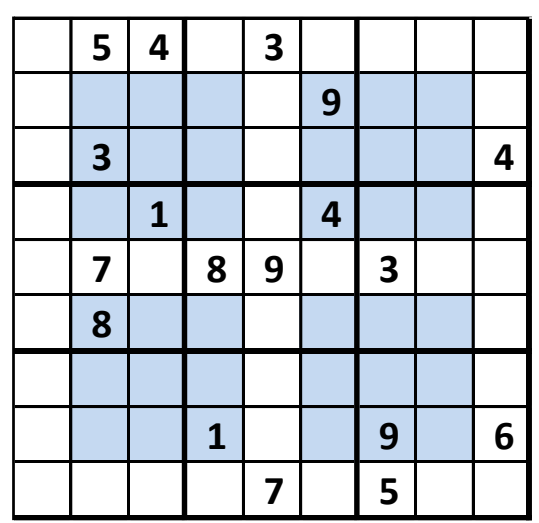

Gambar. 10. Soal Hyper Sudoku B

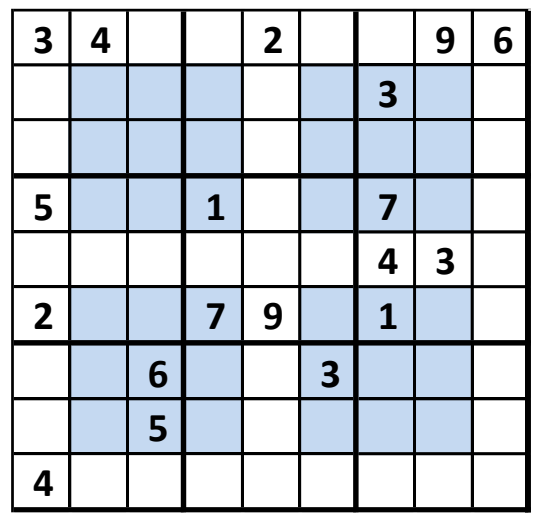

Gambar. 11. Soal Hyper Sudoku C

Ada dua jenis setting parameter yang digunakan pada uji coba ini. Berikut perbandingan hasil kedua setting parameter tersebut pada masing-masing persoalan.

TABEL III

Uji COBA HHO PADA HyPER SUdOKU DENGAN SETTING PARAMETER 1

\begin{tabular}{lccc}
\hline \hline HHO & Soal A1 & Soal B1 & Soal C1 \\
\hline Givens & 15 & 18 & 19 \\
Populasi & 20 & 20 & 20 \\
Iterasi & 100 & 100 & 100 \\
Run & 30 & 30 & 30 \\
Avg Time (s) & 3.952196 & 4.0927832 & 4.0303001 \\
Avg Fitness & 0.8676955 & 0.8680247 & 0.8734774 \\
\hline \hline
\end{tabular}

Uji coba dengan setting parameter 1 menggunakan jumlah populasi 20 dan jumlah maksimum iterasi 100.
TABEL IV

Uji Coba HHO PADA HyPER SUdOKU DENGAN SETTING PARAMETER 2

\begin{tabular}{lccc}
\hline \hline HHO & Soal A2 & Soal B2 & Soal C2 \\
\hline Givens & 15 & 18 & 19 \\
Populasi & 30 & 30 & 30 \\
Iterasi & 500 & 500 & 500 \\
Run & 30 & 30 & 30 \\
Avg Time (s) & 22.141024 & 27.555999 & 27.884046 \\
Avg Fitness & 0.8827572 & 0.8800412 & 0.8825103 \\
\hline
\end{tabular}

$\overline{\text { Uji coba dengan setting parameter } 1 \text { menggunakan jumlah populasi } 30 \text { dan }}$ jumlah maksimum iterasi 500.

Tabel III dan IV digunakan untuk membandingkan hasil antar persoalan Hyper Sudoku, dengan jumlah givens yang berbeda. Pada tabel III, terlihat peningkatan average fitness, namun tidak cukup signifikan. Pada tabel IV agak sedikit berbeda, terlihat average fitness pada soal A2 lebih tinggi dari average fitness pada soal yang lain, meskipun tidak banyak.

TABEL V

UJI COBA HHO PADA HYPER SUDOKU SOAL A

\begin{tabular}{ccc}
\hline \hline HHO & Soal A1 & Soal A2 \\
\hline Givens & 15 & 15 \\
Populasi & 20 & 30 \\
Iterasi & 100 & 500 \\
Run & 30 & 30 \\
Avg Time (s) & 3.952196 & 22.1410238 \\
Avg Fitness & 0.867695473 & 0.882757202
\end{tabular}

Uji coba dengan setting parameter 1 dan 2 pada Hyper Sudoku soal A.

TABEL VI

UJI COBA HHO PADA HYPER SUDOKU SOAL B

\begin{tabular}{ccc}
\hline \hline HHO & Soal B1 & Soal B2 \\
\hline Givens & 18 & 18 \\
Populasi & 20 & 30 \\
Iterasi & 100 & 500 \\
Run & 30 & 30 \\
Avg Time (s) & 4.0927832 & 27.5559993 \\
Avg Fitness & 0.868024691 & 0.880041152 \\
\hline \hline
\end{tabular}

Uji coba dengan setting parameter 1 dan 2 pada Hyper Sudoku soal B.

TABEL VII

UJI COBA HHO PADA HYPER SUDOKU SOAL C

\begin{tabular}{ccc}
\hline \hline HHO & Soal C1 & Soal C2 \\
\hline Givens & 19 & 19 \\
Populasi & 20 & 30 \\
Iterasi & 100 & 500 \\
Run & 30 & 30 \\
Avg Time (s) & 4.0303001 & 27.8840455 \\
Avg Fitness & 0.873477366 & 0.882510288 \\
\hline \hline
\end{tabular}

Uji coba dengan setting parameter 1 dan 2 pada Hyper Sudoku soal C.

Tabel V, VI, dan VII membandingkan hasil antar soal dengan setting parameter yang berbeda, apakah setting parameter 1 lebih baik atau setting parameter 2. Dari ketiga tabel, dapat dilihat bahwa average fitness dengan parameter ke-2 selalu lebih tinggi dari average fitness dengan parameter yang pertama. 
Dari tabel II, dapat dilihat bahwa nilai fitness tertinggi ada pada run ke-2 soal C, dengan menggunakan setting parameter 2, yaitu bernilai sebesar 0.930864198 .

\begin{tabular}{|l|l|l|l|l|l|l|l|l|}
\hline $\mathbf{3}$ & $\mathbf{4}$ & $\mathbf{1}$ & $\mathbf{5}$ & $\mathbf{2}$ & $\mathbf{7}$ & $\mathbf{8}$ & $\mathbf{9}$ & $\mathbf{6}$ \\
\hline 7 & 6 & 5 & 1 & 8 & 9 & 3 & 4 & 2 \\
\hline 4 & 8 & 9 & 2 & 3 & 5 & 1 & 6 & 7 \\
\hline $\mathbf{5}$ & 3 & 4 & $\mathbf{1}$ & 6 & 8 & 7 & 2 & 9 \\
\hline 1 & 7 & 8 & 5 & 9 & 2 & $\mathbf{4}$ & $\mathbf{3}$ & 6 \\
\hline $\mathbf{2}$ & 3 & 5 & $\mathbf{7}$ & $\mathbf{9}$ & 4 & $\mathbf{1}$ & 8 & 6 \\
\hline 4 & 8 & $\mathbf{6}$ & 9 & 5 & 3 & 2 & 7 & 1 \\
\hline 9 & 1 & $\mathbf{5}$ & 4 & 2 & 3 & 6 & 7 & 8 \\
\hline 4 & 8 & 2 & 1 & 7 & 6 & 9 & 3 & 5 \\
\hline
\end{tabular}

Gambar. 12. Angka fitness tertinggi yang dicapai

Pada gambar 12, angka berwarna hitam berarti angka soal, angka berwarna hijau berarti angka yang benar, dan angka yang merah berarti angka yang salah.

\section{KESIMPULAN}

Dari sini hasil uji coba, dapat ditarik beberapa kesimpulan, yang pertama adalah, jumlah givens yang lebih banyak tidak menjamin fitness value yang lebih tinggi. Yang kedua, jumlah populasi dan jumlah maksimum iterasi yang lebih banyak akan meningkatkan fitness value. Yang ketiga, tingkat keberhasilan untuk menemukan solusi pada semua parameter dan persoalan berkisar antara 86-88\%.

Selain itu, dapat disimpulkan bahwa waktu komputasi tidak bergantung pada banyaknya jumlah givens pada persoalan. Namun, untuk perbedaan parameter, jumlah populasi dan jumlah maksimum iterasi, jelas mempengaruhi waktu komputasi secara signifikan.

\section{Daftar Pustaka}

[1] A. A. Heidari, S. Mirjalili, H. Faris, I. Aljarah, M. Mafarja, and H. Chen, "Harris hawks optimization: Algorithm and applications," Futur. Gener. Comput. Syst., vol. 97, 2019, doi: 10.1016/j.future.2019.02.028.

[2] C. Qu, W. He, X. Peng, and X. Peng, "Harris hawks optimization with information exchange," Appl. Math. Model., vol. 84, pp. 52$75,2020$.

[3] Y. Liu et al., "Horizontal and vertical crossover of Harris hawk optimizer with Nelder-Mead simplex for parameter estimation of photovoltaic models," Energy Convers. Manag., vol. 223, 2020, doi: 10.1016/j.enconman.2020.113211.

[4] J. M. Weiss, "Genetic algorithms and sudoku," in Midwest Instruction and Computing Symposium (MICS 2009), 2009, pp. $1-9$.

[5] B. Michel, "Mathematics of NRC-Sudoku," 2007.

[6] M. Weller, "Counting, generating, and solving Sudoku," Ph. D. Diss., 2008.

[7] A. Moraglio and J. Togelius, "Geometric particle swarm optimization for the sudoku puzzle," in Proceedings of the 9th annual conference on Genetic and evolutionary computation, 2007, pp. 118-125.

[8] S. McGerty, "Solving Sudoku puzzles with particle swarm optimisation," Final Report, Macquarie Univ., 2009. 